\title{
STANISLOVO IR LIUDVIKOS DIDŽIULIŲ ORTOGRAFIJOS KAITA: NUO ANTANO BARANAUSKO PRIE BENDRINĖS KALBOS
}

\author{
Jurgita VENCKIENE \\ Lietuvių kalbos institutas
}

\section{Ivadas}

Antano Baranausko lietuviu rašomosios bendrinès kalbos (toliau - rbk) modelio sklaidos tyrimai parode, kad XIX a. pab. - XX a. pr. Žemaičiu (Telšių) vyskupo Mečislovo Paliulionio raštinèje 1881-1908 m. rašyta pagal jo principus $^{1}$. Žemaičių (Telšių) dvasinès seminarijos auklètinių laiškai liudija, kad ne vienam iš ju Baranausko rbk buvo ne tik studijų objektas², bet tinkama kasdieninei komunikacijai raštu, o vèliau taikyta leidžiant lietuvišką spaudą.

Pasauliečiai inteligentai dar prieš pasirodant pirmajam lietuviškam periodiniam leidiniui Aušra (1883-1886) irgi ieškojo tinkamiausio rašyti visiems bendro lietuvių kalbos varianto. Jie taip pat domejjosi Baranausko rbk, dèl to buvo kreipiamasi i minètos seminarijos auklètinius, klausiusius Baranausko lietuvių kalbos paskaitų. Tai liudija ir Jono Spudulio 1883 m. laiškas tuometiniam seminaristui Adomui Dambrauskui: „Dżiaugdamasi prisipażistu, jog pirmuoju mano mokintoju tiesraszczio lietuwiszko buwo Kun. Baranauskis pawizdije tos gramatikos, katrą asz gawau isz Kauno ir katrą tu pats matei“ (Spudulis 1883-12-03: [1r]).

Šiame straipsnyje tęsiami Antano Baranausko rbk sklaidos už Žemaičiuc (Telšių) vyskupijos raštinès ir dvasinès seminarijos ribų tyrimai: analizuojama jo sekejju Stanislovo Didžiulio (18503-1927), pagarsèjusio dèl savo lituanistinès bibliotekos ${ }^{4}$ ir lietuviškos spaudos platinimo bibliofilo, bei jo žmonos rašytojos Liudvikos Nitaitès-Didžiulienès-Žmonos (1856-1925) rašomosios kalbos kaita. Griežionėles, kur gyveno Didžiuliai, Petras Jonikas minėjo greta kitų „lietuviškos veiklos židinėli[u]“ - Rygos, Mintaujos, Panemunèlio. Čia lankèsi Jonas Basanavičius, Jonas Jablonskis, Juozapas Miliauskas-Miglovara (Jonikas 1987: 291).

Didžiulių rankraštini palikimą sudaro $1872-1925$ m. rašyti tautosakos (dainų, pasakų, mįslių, patarlių, priežodžių), leksikos rinkiniai (vietovardžių,

1 Plačiau žr. Venckienè 2014: 269-294.

2 Baranauskas 1870-aisiais vyskupo Motiejaus Valančiaus paskirtas seminarijoje dèstyti homiletiką - pamokslų sakymo teoriją ir praktiką lietuvių kalba (Venckiené 2014:269).

3 Tokią gimimo datą yra nurodęs Vaclovas Biržiška (B[iržiška] 1954a: 528), taip pat Benjaminas Kaluškevičius ir Kazys Misius (Kaluškevičius, Misius 2004: 117), Vladas Žukas (Žukas 200308-06 [žiūrèta 2019-04-01]). Anykštènų biografiju žinyne nurodyti 1856 m. Teigiama, kad data nustatyta pagal Anykščių parapijos krikšto metrikus (žiūrèta 2019-01-22).

4 Plačiau žr. Lietuvninkaitè 2004a: 9-29. 
asmenvardžių, augalų pavadinimų), etnografiniai, bibliografiniai ir kitokie užrašai, Didžiulienès kūryba, egodokumentai. Šių rankraščių tyrimas ne tik parodo Baranausko rbk sklaidą, bet ir atskleidžia, kaip paskutiniuoju XIX a. dešimtmečiu ir XX-ojo a. pradžioje Didžiulių rašomąją kalbą veikè vis didesnị prestižą igyjanti lietuviškų periodinių leidinių kalba.

\section{Stanislovas Didžiulis}

Stanislovas Didžiulis, gimęs Griežionèlèse, Anykščių rajone, bajorų šeimoje, baigè tris Panevèžio gimnazijos klases, paskui privačiai mokėsi pas Andrioniškio kunigą Antaną Viskantą̧5 (B[iržiška] 1954a: 258). Kaip teigia Nijolė Lietuvninkaite, įtakos Didžiulio „dvasiniam ir kultūriniam brendimui turèjo bendravimas su aplinkiniais anykštėnais inteligentais prelatu Antanu Pavilioniu ${ }^{6}$, būsimu vyskupu kunigu Antanu Karosu ir jo broliais ${ }^{7}$, Antanu Baranausku“" (Lietuvninkaite 2004a: 11). Veikiausiai jau tada pradèta pažindintis ir su Baranausko rbk modeliu.

\subsection{Didžiulis ir Baranausko rbk}

Lietuvninkaitės parengtas Didžiulio bibliotekos katalogas liudija, kad joje būta ir Baranausko gramatikos, tiksliau, jos nuorašų (Lietuvninkaite 2004b: 171). Kataloge nurodytos dvi rankraštinès knygos, aprašytos pagal paties Didžiulio sudarytą sąrašą:

(1) Kalbomoklis Lëtuwiszko Lëžuwio: dalis ketvirta / Sudarymas (A. Baranausko) Rankrašty S. Didžiulio rašytame,

(2) Mokslas Lëtuwiszkos kalbos / (A. Baranausko) Rankrašty S. Didžiulio ranka rašytame. - 214 p. (Lietuvninkaitė 2004b: 171).

Iš Baranausko laiško Didžiuliui matyti, kad 1872 m. gruodị Didžiulis persirašinėjo kalbomokslį: „,Kałbómokslo, kad dár noréjai paturéti, neużsipúłu. Siunczù atgalós, mażìr lig ażùgawenioms spési pérsiraszyti“ (Baranauskas 187212-21: 161).

Kalbinès medžiagos Baranausko prašyta ir vèliau:

Jeigù ir tolaũs Jũsu Mýlista gérą szìrdị turési ant músu, tai praszymams músu ne bùs ir gało: idant jeigù wérti bùtumemè tós Mỹlistos,

5 Antanas Viskantas (1813-1897), Vilniaus kunigų seminarijos auklètinis, Andrioniškyje dirbo 1867-1870 m. (Anykštènu biografiju žinynas [žiūrèta 2019-01-22]).

6 Kunigas Antanas Pavilonis (1847-1918) vèliau, 1892-1895 m., Žemaičių (Telšių) dvasinèje seminarijoje dèstẻ lietuvių kalbą (Jonikas 1987: 362).

7 Didžiulio bendraamžis kunigas Antanas Karosas (1856-1847) Žemaičių (Telšių) dvasinėje seminarijoje pakeitė Baranauską, dėsčiusį homiletiką ir lietuvių kalbą, 1883-1885 m. (Jonikas 1987: 362). Jo broliai Kazimieras Karosas (1861-1917) - gydytojas, ir Klemensas Karosas (1866-1933) - inžinierius kelininkas (Anykštènų biografiju žinynas [žiūrèta 2019-01-22]). 
gãuti pérkaityti: Kałbómokslį sutrumpitą, apë kurị J. M. minejai, Móksłą Szwentós ìszkałbos.

Ir teíp wëną rásztą parsiùntę mełstumem kito; dabàr žëmós łaikè turétumem kadą mókytës (Didžiulis, Didžiulienè 1878-11-29: [1-2]).

Pats Didžiulis laiške nenustatytam adresatui yra užsiminęs, kad rašąs remdamasis Baranausko kalbomoksliu:

Raszydamas lëtuwiszkai turiůs kałbomokslo musu mylimiausio ir garbingiausio gilai mokyto kałbos tyrejjaus Jo Mylistos Prałoto Antano Baranausko, žinama, tëk, këk suprantu, o ko neiszmanau, raszau ant nůmones (Didžiulis [b. d.]: [1]).

Taigi Didžiulis Baranausko gramatikos nuorašus turèjo ne tik kaip įdomius, vertingus lituanistinès kolekcijos vienetus, bet naudojo juos pagal paskirtị - mokèsi rašomosios kalbos. Iš minèto laiško matyti, kad Didžiulis palaike Baranausko rbk, kuri koduotų skirtingų tarmių ypatybes, ideją̨: ,Tamsta sakai raszyti pagal tarmenio_ jegu kožnas (kekwënas) Letuwninkas raszys pagal sawo tarmenio tai neturesime wenos raszybos, bet tëk kek yra tarmeniu“ (Didžiulis [b. d.]: [1]). Čia jis argumentavo ir rašmenų $<\stackrel{\mathrm{u}\rangle}{\rangle},\langle a ̨\rangle,\langle e ̨\rangle$, reiškiančių skirtingai tarmèse tariamus garsus, vartoseną:

Jeigu wëtoje ů raszysime uo tai mum tiks: raszont duok man juodos duonos, bet kaipgi skaitys të lëtuwnįkai, kurë isztaria: douk man joudos dounos.

Iszmetus isz musu abecełes ,,ą“ kaip reiks raszyti - žąsis; asz raszysiu žusis, o kai kiti raszys žansis[,] žasis, žonsis, žosis.

Jeigu wetoje ę raszysime en (mes isztariame in) tai žodžwardįs „buwęs“ bus „buwens“ tai aszei skaitysiu buwins (ba szwentos, menkos asz sakau szwintos, minkos“) o man reikia skaityti „buwis“ (Didžiulis [b. d.]: [2]).

Taigi laikydamasis Baranausko rbk principų, Didžiulis kodavo gimtosios anykštènų tarmès formas.

Ankstyviausius išlikusius - XIX a. aštuntojo dešimtmečio pradžios - rankraščius Didžiulis rašè remdamasis Baranausko rbk. 1872-aisiais datuotame smulkiosios tautosakos rinkinėlyje Priežodžiai, patarlès, papročiai, mįslès, burtai ir pasakos (Didžiulis 1872) vartotos tuo metu ịprastos (būdingos ir Baranausko rbk) raidès <cz $>$ (bažnýczon [1]), <sz $>$ (szakàs [1r]), <ł [1] ir $\langle\mathrm{l}\rangle$ [1’] (laúkq [1], plg. ir Nulúdo [1]), <w> (gałwós [1]). Orientaciją i Baranausko rbk

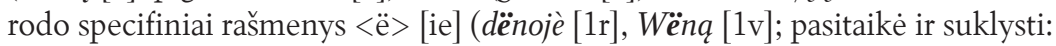

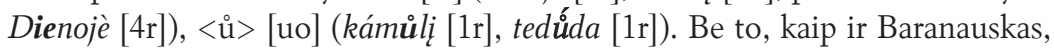
Didžiulis čia nežymèjo priebalsiu [č'], [dž] minkštumo prieš užpakalinès eilès 
balsius (buczoja [1r], ant peczú [1r], szwenczausià voc. sg. [1r]; médžq acc. sg. [1r], prëžodžai [3r]). Kaip matyti iš pavyzdžių, Didžiulis stengèsi žymèti ir kirčio vietą.

Atrodytų, kad tuo metu Didžiuliui buvo ịprasčiau dvibalsius [ai], [ei], [ui] tradiciškai žymèti su $<-\mathrm{j}>-$ taip jie rašyti 1. 3r, bet taisyta į baranauskišką $<-\mathrm{i}>$, pvz. (iš eilès): Présakaj $\rightarrow$ Prë́sakaí, rejszkia $\rightarrow$ reiszkia, lájme $\rightarrow$ táime, mëjles $\rightarrow$ mëiles, wajkaj $\rightarrow$ waikaí, wargaj́ $\rightarrow$ wargaí, szúniuj $\rightarrow$ szúniui.

Remdamasis Baranausko rbk Didžiulis aptariamajame rinkinèlyje rašè ir (i) $\bar{a}, \bar{e}$ kamienų vardažodžių instr. sg. galūnes -q (wënà jưstelà $[2 \mathrm{r}]$ ), $-e$ (bobutè [1v]) (žr. 1 lentelę).

Tokios ortografijos ypatybès būdingos ir $1881 \mathrm{~m}$. datuotam dainų rinkinèliui (Didžiulis 1881): rašyta <cz> (waikszczůdama [2r]), <sz> (rëszuti [3r]),

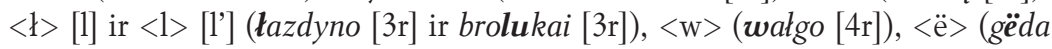

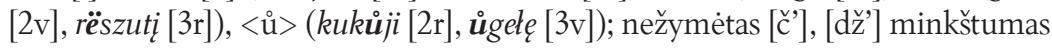
prieš užpakalinès eilès balsius (sweczu gen. pl. [5r]; gardžai [4r]). Gen. pl. galūnëje, kaip ir Baranauskas, Didžiulis nerašè nosinès raidès (augsztu kalnelu [2v], pëtu [4r]). Tačiau žodžių kirčio šiame dainų rinkinèlyje jis nebežymėjo.

\subsection{Pereinamasis Didžiulio ortografijos laikotarpis}

Netrukus, devintojo dešimtmečio pradžioje, Didžiulis ėmè abejoti dèl savo rašomosios kalbos pasirinkimo - Baranausko rbk jis nebesilaike taip nuosekliai. Dirvų tręšimo žiniaraštyje (Didžiulis [1875-1882]), $1882 \mathrm{~m}$. greta ankstesnei jo kalbai būdingų $<\mathrm{cz}>$ (griczos [1v]), $<\nmid>$ (mežłu gen. pl. [1v]), [dž] minkš-

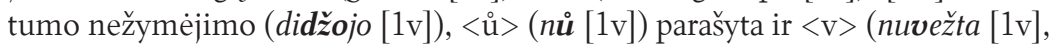
Viralu $[1 \mathrm{v}]),<\mathrm{ie}>$ (vietos [1v]), <uo $>$ (metuose [1v]).

$1883 \mathrm{~m}$. Juozapo Miliausko-Miglovaros parengtame rankraštiniame laikraštėlyje Poczta Litewsko-Literacka (Raszliavos Pacztas) ([Miliauskas-Miglovara] 1883) esančių Didžiulio iૃrašu (p. 18 ir 21), datuotu 1883 m. gruodžio $21 \mathrm{~d}{ }^{8}$, rašyba irgi įvairuoja. Miliausko tekstai čia rašyti lenkiškai, tad Didžiuliui nereikèjo taikytis prie Rašliavos Pačto ortografijos.

Pirmojo ịrašo pirmoje eiluteje Didžiulis dar rašè $<\mathrm{w}>$ (Milewskio, wisiszkai), toliau - tik <v>, plg. (iš eilès): Raszliavos, Lietuvis, savęs, visà instr. sg. f., savo, savo szventq vierq, evaneliczku, suvisu, vienok, vaikams, inbrukdavo). Priebalsị [1] žymėjo <l> (kalbos $2 \times$, labai, tulai [išskyrus tik altoriku]), [1'] prieš užpakalinės eilès balsius - $<\mathrm{li}>$ (galiu, raszliavoje, Raszliavos, raszliavos). Du kartus paraše $<$ uo $>$ (Juozapa, parduodas), $1 \times-<\stackrel{\mathrm{u}}{>}$ (n⿺̊)), taip pat $<\mathrm{ie}>($ apszvietimo, Lietuviams, niekas, vienok). Tačiau vis dar nežymejjo [dž] minkštumo (szirdžą instr. sg.), baranauskiškai rašè instr. sg. f. visą szirdžą ir gen. pl. „,bukvu“. 8 Didžiulio nurodytas siekio mènesis veikiausiai reiškė gruodị (taip vadintas ir sausis, plg. $L K Z ̌ e$ ),
nes Rašliavos Pačte minima Aušra, tepradèjusi eiti 1883 m. kovo ménesị. 
Antrasis Didžiulio įrašas to paties rankraštinio leidinio numerio p. 21 labai panašus, net [uo] vèl žymètas dvejopai (taigi dviraidis $<$ uo $>$ Didžiuliui veikiausiai dar neįprastas), plg. (iš eilès): ků, duota, szaukiuos, amžiůse, iszdůtas, metuose. Iš p. 18 nepasitaikiusių atvejų minètinas [č’ minkštumo nežymėjimas p. 21 (galecza cond. 1 sg.).

Aptariamieji įrašai Rašliavos Pačte nuo ankstesnių Didžiulio rankraščių skiriasi ir tuo, kad juose nèra raidès $<y>$ ilgajam balsiui žymèti (plg. daugibe 18, miliu 21). Ši raidè nevartota ir Aušroje nuo 1883 m. 6 numerio. Jonikas, remdamasis Basanavičiumi, teigè, $\mathrm{kad}<\mathrm{y}>$ (ir $<\mathrm{l}>$ bei gen. pl. galūnès diakritinių ženklų) atsisakė Aušros redaktoriumi tapęs Jonas Šliūpas (Jonikas 1972: 227). Čia prisimintina, kad nuo 4-ojo 1883 m. numerio Aušroje vartota ir raide $<\mathrm{v}>$ ? Taigi Didžiulio rašybai įtakos galejo turèti būtent šio laikraščio pasirodymas ir jo kalba. Kita vertus, Aušroje vartota $<\grave{\mathrm{u}}>$, o Didžiulis, regis, jau stengèsi rašyti $<$ uo >; Aušroje žymètas [č’], [dž] minkštumas prieš užpakalinès eilès balsius, o Didžiulio ịrašams tai nebūdinga.

1889-03-24 datuotas Didžiulio laiško nenustatytam vyskupui ${ }^{10}$ juodraštis (Didžiulis 1889-03-24) vèl rašytas ankstesne rašyba - laikantis Baranausko rbk

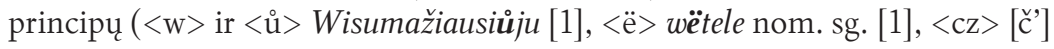
be minkštumo ženklo prieš užpakalinès eilès balsius: płaczus [1], gen. pl. tarnu [1]). Veikiausiai ortografijos modelio pasirinkimą čia lèmė adresatas, t. y. Baranauskas ar kitas vyskupas (kaip minèta, Žemaičių [Telšiu ] vyskupo raštinejje rašyta Baranausko rbk). Vadinasi, devintajame dešimtmetyje Didžiulis rašè dvejopai - ir baranauskiškai, ir pagal Aušrą.

Dvejopą ortografiją iliustruoja ir 1890-08-25 Didžiulio laiškas Matynui Jankui kaip Ükininko redaktoriui (Didžiulis 1890-08-25). Šiame laiške Didžiulis rašè Baranausko raides $<\ddot{e}>$ (dënose [1]) ir $<$ ů $>$ (šiümi [1]) (Varpe [1889-1905] ir Ūkininke [1890-1905] <ё $>$ nebuvo, o $<\stackrel{\mathrm{u}>}{>}$ pradèta vartoti vèliau, abiejuose laikraščiuose nuo 1892 m. 4/5 numerio), bet [1] rašè <l> (labas acc. pl. f., nors dar pasitaike ir kłotës [1]), taip pat $<\mathrm{v}>($ Tavo [1]), žymėjo [dž] minkštumą (meldžiu [1]).

Be to, laiške Jankui Didžiulis jau rašè diakritinę < ̌̌̀ $>$ (dešimtị [1], rašiau [1]), mègintą vartoti Aušroje (tik 1883 m. 5 numeryje, redaguotame Jono Basanavičiaus) ir vèlèliau (nuo 1890 m.) ịsivestą Varpe (bet Ūkininke tik nuo 1894 m.). Priebalsị [č] šiame laiške Didžiulis žymėjo raide $\langle$ ç $\rangle$, t. y. $\langle$ c $\rangle$ su diakritiku apačioje - cedilija, bet jo minkštumas ženklu <i $>$ nežymètas (siunçant [1], prašyçau [1]). Prie aptariamojo laiško pridèta sakmè „Voras“, čia išlaikyti tie patys ortografijos principai kaip ir laiške.

\footnotetext{
9 Plačiau apie Aušros redaktorius ir kalbos kaitą žr. Venckienè 2007.

${ }^{10}$ Laiške kreipiamasi ị vyskupą. Žemaičiu vyskupas tuo metu buvo Mečislovas Paliulionis; laiškas galèjo būti skirtas ir pačiam Baranauskui, tuo metu vyskupui sufraganui, t. y. pavyskupiui.
} 
Rašmenų $<\mathrm{l}>$ [1], $<\mathrm{s}\rangle,\langle\mathrm{v}\rangle$, [dž] minkštumo prieš užpakalinès eilès balsius žymėjimas rodytų, kad taikytasi prie Ükininko ortografijos. Tačiau raidès $<c ̧>$ tame leidinyje nebuvo. Išlikusioje Didžiulio korespondencijoje apie [č] žymèjimą nẻra jokių užuominų, tad belieka spèti, kad galbūt apie raidyną buvo diskutuojama asmeniškai. Juo labiau, kad vèliau, 1899 m., tokią raidę knygelèje Prie historijos musun rašybos vartojo Basanavičius. Rašmeniu <ç> jis žymejjo [č] žodžio pradžioje ir skoliniuose:

Del paženklinimo to garsmo, kurin su lyg' šiol' lenkiškai $c z$, čekiškai č išreikšta, turime investie ipatingan ženklan c su vůdegaite apaţioje (ç) ir jin tik prad̦ioje, prasidedanţiun nů to garsmo žod̦iun, kuriun musun kalboje teipogi mažai randasi, ir paimtůse iš svetimun kalbun - ipațiai iš sloveniškun - vartotie ([Basanavičius] 1899: 12).

Kitose žodžio pozicijose Basanavičius [č] ženklino rašmeniu $<\mathrm{t}\rangle$ : „Žemaitijoj, kur ji dar nesuminkštinta liekti, tur šita ţ kaipo prasta t išsitartie“ ([Basanavičius] 1899: 13). Dar prieš pasirodant šiai knygai, Basanavičiaus rašyba Didžiuliui galèjo būti pažistama ir iš asmeninių pokalbių (kaip minèta, Basanavičius buvo lankęsis Giežionèlèse), ir iš bibliotekoje turètų knygų Oškabaliu dainos (Basanavičius 1884), Žiponas bei žipone ir auksingumas bei sidabringumas lietuviškun dainun (1885) ir Žirgas ir vaikas (1885) (plg. Lietuvninkaite 2004b: 58-59). Tiesa, šiose knygose Basanavičius $<c ̧>$ dar nevartojo, plg. Oškabaliu dainas: ţebataiţius ‘čebataičius' 34, Ţion ‘čion’ 43(8×). Be to, Basanavičius [dž] ženklino $<$ d, $>$, o Didžiulis tokios raidès nerašè.

Tad devintąị dešimtmetị Didžiulis tarsi lūkuriavo, kuri ortografija ịsitvirtins, pagal poreikį remdamasis vienu ar kitu ortografijos modeliu, pasirinkdamas $<$ cZ $>$

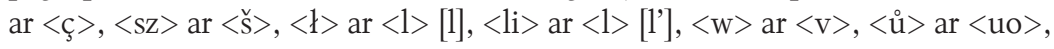
$<\ddot{\mathrm{e}}>$ ar $<$ ie $>$, nežymėdamas ar žymėdamas [dž’] minkštumą (plg. 1 lentelę).

\subsection{Orientacija ị periodikos kalbą}

1897 m. pabaigos ir 1898 m. pradžios laiškuose žmonai (Didžiulis 189712-08, 1897-12-26, 1898-01-14, 1898-01-28) Didžiulis jau vartojo periodi-

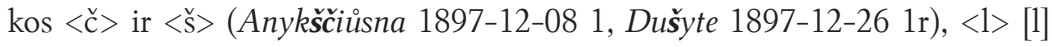
(mokslưse 1897-12-26 1v), <v> (šventes nom. pl. 1897-12-26 1r), rašė <ie > (dienoje 1898-01-14 2v, Dievo 1897-12-26 1r), be to, žymėjo [č’] minkštumą prieš užpakalinès eilès balsius (priežasčiu gen. pl. 1897-12-08 1; plg. 1 lentelę). Vartosena nuosekli, be suklydimų. Tokią ortografijos permainą lëmé bendravimas su varpininkais (1892-1896 m. Didžiulis dalyvavo jų suvažiavimuose ir pasitarimuose [B(iržiška) 1954a: 529]), bendradarbiavimas varpininkų spaudoje, taip pat ir stiprejjantis periodikos kalbos prestižas.

Iš Baranausko rbk paskutiniaisiais XIX a. metais Didžiulis beraše tik raidę

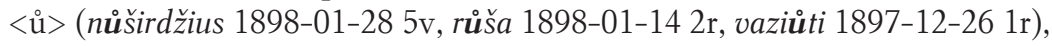


taip pat žymèjo nosinę raidę instr. sg. f. galūnèje (su pagelbq 1898-01-28 6r, su Tamsta 1898-01-28 4r), nežymèjo nosinès raidès gen. pl. galūnèje (bernioku 1898-01-28 4r, žmoniu 1897-12-26 1r).

Daugiau savo rašybos Didžiulis nebekeitè, nors ji dèl likusių Baranausko rbk ypatybių (<น̊> , instr. sg. f., gen. pl.) ir neatitiko nei Varpo, nei 1901-ųju Jono Jablonskio gramatikos ir vèlesnių jo darbų (1917, 1918, 1919). Ir XX a. antrajame dešimtmetyje, kaip buvo pratęs, jis teberaše $<\stackrel{\mathrm{u}}{>}$ (darbůties 191503-19 20, surǔšiau 1916-06-16 8r), instr. sg. f. su -q, -ę (su šeimyna 191503-19 20, su šveicariškq markele 1915-03-19 20), gen. pl. su -u (Sukaktuviu 1916-04-29 6r). Tokia rašyba skyrèsi nuo tuometinès bk.

Nuo 1907-ųju iki 1917-ųjų gyvendamas tremtyje Sibire (B[iržǐ̌ka] 1954a: 529), Didžiulis nebesirūpino laikytis vieno ar kito ortografijos modelio ar keisti rašmenis. 1916 m. jis rašè dukrai, kad svarbiausia - neužmiršti savo kalbos: „Nors neužtektinai tu laikrašteliu ${ }^{11}$, bet nors gi savos gimtosios kalbos ne užmiršiu. Ar tikesi, kad aš par tůs septinelius metus nekuriůs žodžius primiršau“ (Didžiulis 1916-06-16: [8r]).

Jablonskio gramatikų neatitikusi Didžiulio ortografija XX a. pradžioje nebuvo išimtinis atvejis. Tai patvirtinta Adomas Jakštas-Dambrauskas: tapdamas inteligentijos leidinio Draugija (1907-1938) redaktoriumi jis tikejjęsis, kad šio leidinio autoriai rašys jablonskiškai ir jų kalbos nebereikès taisyti. Vis dèlto 1914 m. jis guodèsi, kad daugumos „,bendradarbių rašiniai reikejjo ir nun vis da tebereikia taisyti ir gerokai taisyti“ (Jakštas-Dambrauskas 1914: 25).

1 lentele

Stanislovo Didžiulio ortografijos kaita

\begin{tabular}{|c|c|c|c|c|}
\hline & 1872 & 1882-1889-03-24 & 1890-08-25 & nuo 1897-12-26 \\
\hline$[\check{c}],[\check{s}]$ & $<\mathrm{cZ}>,\langle\mathrm{sZ}\rangle$ & $<\mathrm{cz}\rangle,\langle\mathrm{sz}\rangle$ & $\langle\mathrm{c}\rangle,\langle\mathrm{s}\rangle$ & $\langle\check{\mathrm{c}}\rangle,\langle\mathrm{s}\rangle$ \\
\hline$[1]$ & $<\mathrm{l}>$ & $<\mathrm{l}>$ ir $<\mathrm{l}>$ & $<1>$ & $<\mathrm{l}>$ \\
\hline$[\mathrm{v}]$ & $<w>$ & $\langle\mathrm{w}>$ ir $\langle\mathrm{v}\rangle$ & $<\mathrm{v}>$ & $<\mathrm{v}>$ \\
\hline [ie] & $<\ddot{\mathrm{e}}>$ & $<\ddot{\mathrm{e}}>$ ir $<$ ie $>$ & $<\ddot{\mathrm{e}}>$ & $<\mathrm{ie}>$ \\
\hline [uo] & $<\stackrel{\mathrm{u}}{ }\rangle$ & $<$ i̊ $>$ ir $<\mathrm{uo}>$ & $<\stackrel{\mathrm{u}}{ }>$ & $<\stackrel{\mathrm{u}}{ }>$ \\
\hline [č'], [dž'] & $\langle\mathrm{cz}\rangle,\langle\mathrm{d} z ̌\rangle$ & $\langle\mathrm{cz}\rangle,\langle\mathrm{dž}\rangle$ & $\langle\mathrm{c}\rangle,\langle\mathrm{d} z ̌ \mathrm{i}\rangle$ & $<$ či $>,<$ dži $>$ \\
\hline instr. sg. f. & $-q,-q$ & $-q,-q$ & $-e$ & $-q,-e$ \\
\hline gen. pl. & $-u$ & $-u$ & $-u$ & $-u$ \\
\hline
\end{tabular}

${ }_{11}$ Iš Didžiulio laiškų žinoma, kad 1910 m. jis skaite Lietuvos Žinias, Ukininkq, Viltị, Litwq ir Šaltinị (Didžiulis 1910-12-30:[15v]), 1912 m. - Lietuvos Žinias, Ukininka, Vilti, Litwa, Bendrija, Pasiuntinį, Laisvają Mintį, Laisvę ir Naša Niva (Didžiulis 1912-06-17: [7v]). 


\section{Liudvika Nitaitè-Didžiulienè-Žmona}

Liudvika Didžiulienė atsiminimuose rašè, kad susipažinusi su Didžiuliu gavo iš jo knygų: jis davęs ,gramatiką Krzyžanovskio ir gramatiką arba 'Kalbomoksli’ A. Baranausko, pagal kurio aš ir rašyt tuojaus pradejau" (Didžiulienė [b. d.]: 89).

\subsection{Didžiulienè - Baranausko rbk sekèja}

1875-11-16 datuotą laišką būsimam vyrui Nitaitè (Nitaite 1875-11-16) rašè Baranausko rbk būdingais rašmenimis $\langle 1>$ [1'] (be minkštumo ženklo; dalòs,

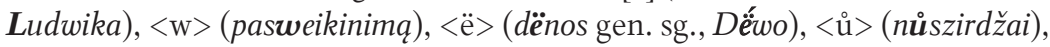
nežymèjo priebalsiu [č’], [dž’] minkštumo prieš užpakalinès eilès balsius $(<\mathrm{cz}\rangle$ : mylinczos, Nitaicza; <dž>: nůszirdžai).

Smulkiosios tautosakos rinkinyje Senujų kalbos ([Didžiulis, Didžiulienė b. d.]), veikiausiai rinktame abiejų Didžiulių, dalis įrašų pažymèti inicialais L. D., tad rašyti Didžiulienès. $1881 \mathrm{~m}$. datuoti jos ịrašai irgi baranauskiški $(<\nmid>$ [1] Iszakkaú 1881-09-05 19, gakwà 1881-09-03 23, <l> [1'] kláutës 1881-0903 23, <sz> szepetys 1881-09-03 4, <w> Dowanà 1881-09-03 11, <ë> Dënq 1881-08-06 11, <ů> Jůksếs 1881-09-03 23; [č'], [dž] prieš užpakalinès eilès balsius: plaúczai 1881-09-05 19, žódžo 1881-09-05 19; gen. pl. sziaudú 188109-05 19; plg. 2 lentelę).

\subsection{Pereinamasis Didžiulienès ortografijos laikotarpis}

Minètame tautosakos rinkinyje Senujų kalbos po kelerių metų, 1885-0415 datuotą įrašą Didžiulienè parašè $\mathrm{su}<\mathrm{l}\rangle$ [1] (susivalgo 11 ), $\langle\mathrm{v}\rangle$ (nenusidavus 11), o 1887-12-29 - ir <ie > (Dieve 11). 1888 m. ji čia rašè $<\mathrm{v}>$ (Žuvis 18880457 pakavojęs 1888-03-28 31; bet ir atwes 1888-03-17 23), <ie> (svietas 1888-03-17 17; bet ir Jёdu 1888-03-17 23).

Tad devintajame dešimtmetyje Didžiulienė, kaip ir jos vyras, ėmè bandyti periodikoje vartotus rašmenis. Vèlèliau, nuo $1892 \mathrm{~m}$., ji pradejo bendradarbiauti Varpe ir varpininkų leidiniuose (B[iržiška] 1954b: 256).

1895-10-17 laiške vyrui Didžiulienė (Didžiulienè 1895-10-17) teberašè $<\mathrm{cz}>$ (Skaicziau 1v), <sz> (Duszyte 1r), <w> (Tewelius 1v, waikszczioja 1v), instr. sg. su $-q$ (su skepeta $2 \mathrm{v})$, gen. pl. su $-u($ Teweliu $1 \mathrm{v})$, tačiau nebevartojo $<\nmid>$ (jilga 1r, ne sulaukdama 1r, klausiau 1v; taip pat plg. markeliu gen. pl. 1r, Teweliu gen. pl. 1v), Baranausko <ë> (dienos gen. sg. 1r, diena 1r), pradejjo žymèti [č'], [dž’] minkštumą ([と̌’] bažnyczios 1r, Skaicziau 1v, waikszczioja 1v; [dž] didžiai $1 \mathrm{r}[2 \times]$, džiaugsmas $1 \mathrm{r}$ ).

1896 metų rudenį Didžiulienè su vaikais išvyko gyventi į Mintaują (B[iržiška] 1954b:256). Iš ten vyrui rašytuose laiškuose (Didžiulienė 1896-09-15) nuosekliai teberašè < instr. sg. f.(su garbe 1896-09-15 2) ir gen. pl. galūnes (mokitiniu 1896-09-15 2). 
Atsisakiusi rašmens $\langle 1>$, beveik nesuklysdama rašè $<\mathrm{l}>[1]$ ir $<$ li $>[1$ '] prieš užpakalinès eilès balsius ( $<\mathrm{l}>$ :laiške 1896-09-15 1, Szlapelio 1896-09-15 3; <li $>$ : kąnelius 1896-09-15 1, rubliu gen. pl. 1896-09-15 3); labai retai tepasitaikè parašyti $\langle\nmid>$ (užłaikima 1896-09-15 3). Ir vèliau [1] ir [1'] žymèjimas nebevarijavo. Nesuklysdama rašè ir $<$ ie $>$ vietoj Baranausko $<\ddot{e}>$. Tačiau priebalsių [č], [̌̃], [v] žymejjimas buvo nevienodas.

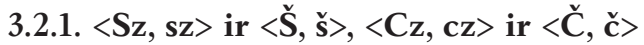

Kaip minèta, Didžiulis diakritinę $<$ š $>$ jau vartojo 1890 m., o $1897 \mathrm{~m}$. buvo igudęs rašyti ir $\langle\check{c}\rangle$. Nors nėra išlikusių $1896 \mathrm{~m}$. jo laiškų žmonai, veikiausiai ir tada jai rašè su $<\check{\mathrm{c}}\rangle,\langle\mathrm{s}>$. Tad ir Didžiulienè, gaudama iš vyro laiškus su diakritiniais rašmenimis, $1896 \mathrm{~m}$. rudeni pamėgino rašyti $<\breve{s}\rangle$. Vis dèlto laiškuose dar dominavo <Sz, sz>, pavyzdžiui, 1896-09-15 laiške (Didžiulienè 1896-09-15; iš eilès): aszaru išspaude 1, szneketi 1, laiszke 1, paszaukti 1, barszczius 1, Ne rasziau 1, paszaukti part. pass. nom. pl. m. 1, prisirůsze 1, ǐs 2, Szlapelis $2(2 \times)$, dešimtị 2, szeszi 2, išwažiawo 2, išeina 3, deszimtes gen. sg. 3, jeszko 3, deszims 4, kasztawojo 4, szendien 4, praszau 4(2×), augszta 4, wiškai dat. sg. 4, szepele 4, praszau 4. Bet netrukus Didžiulienè nustojo eksperimentuoti žymėdama [š] ir toliau rašè ankstesnę $<\mathrm{Sz}, \mathrm{sz}>$.

1897-05-04 laiške Didžiulienė vèl rašè $\langle$ Š, š $>$, o kartu ir $\langle$ Č, č $>$; be to, šios raidès daug dažnesnès negu anksčiau. $\langle\grave{S}$, š $\rangle$ ir $\langle$ Sz, sz $>$ santykis 32 ir 2 , bet to, dar $1 \times$ parašyta $\langle$ s $>-$ be diakritiko (waikscziojome 2 ). Raidę $<$ Č , č $>$, regis, rašyti buvo kiek sunkiau, $\langle\check{\mathrm{C}}, \check{c}\rangle$ ir $\langle\mathrm{Cz}, \mathrm{cz}\rangle$ santykis 7 ir 11, plg. (iš eilès): petnicziq 1, waikščiojant 1 , gaištančiu karwycziu 1, czia 2, treczias 2, prawerczia 2, prašyczio 2, Czionai 2, waikscziojome 2, Michajlawicziene 3, Repeczkienes 3, werčiaus 3, čionai 3, ne norečia 3, čia 3, pawaikščios 3, siuncziu 3.

\subsection{2. $\langle\mathrm{W}, \mathrm{w}\rangle$ ir $\langle\mathrm{V}, \mathrm{v}\rangle$}

1897-03-01 laiške vyrui Didžiulienè vèl prisiminė dar užrašant tautosaką vartotą $<\mathrm{v}>$ : ją parašè 6 kartus (Dievui 1, Vaiciuszka 3, Vaiciuszkai 2, Vain. [Vaineikis - J. V.] 1, Vilniun 2, vyriausio 3), bet matyti, kad $\langle\mathrm{w}>$ kur kas ịprastesnè - ji keturis kartus dažnesnè (28×), plg. (iš eilès): wakar 1, sweiki 1, Kwat [e]ra 1, wisiems 1, ne apsigywino 1, kwateru 1, kwateros 1, tewai 2, atwažiů 2, buwau 2, wieno 2, walia 2, kwateras 2, wažiůisiu 2, wažiůti 2, nuwažiawau 2, padawiau 2, wiltis 2, parwažiawo gywinti 2, wietinis 3 , waliq 3 , Silwestraitiene 3, Awižonis 4, iszwažiavau 4, ketwirtoje 4, wakar 4, batwiniu 4). Po keleto mènesių situacija pasikeitė: 1897-08-25 laiške (Didžiulienė 189708-25) jau dažnesnè $\langle\mathrm{v}\rangle$ : santykis su $\langle\mathrm{w}\rangle-10$ ir 1 .

Vis dèlto $1897 \mathrm{~m}$. negalima fiksuoti galutinio apsisprendimo, perejjimo nuo Baranausko prie periodikos ortografijos normų. Po vasaros atostogu $1897 \mathrm{~m}$. rudenị sugrịžusi ị Mintaują Didžiulienè vèl pramaišiui raše $<\mathrm{Cz}, \mathrm{cz}\rangle$ ir $\langle\check{\mathrm{C}}, \check{\mathrm{c}}\rangle,\langle\mathrm{Sz}, \mathrm{sz}\rangle$ ir $\langle\breve{\mathrm{S}}, \breve{s}\rangle,\langle\mathrm{W}, \mathrm{W}\rangle$ ir $\langle\mathrm{V}, \mathrm{v}\rangle$, o, pavyzdžiui, 1898-02-28 
laiške vyrui (Didžiulienė 1898-02-28) nebuvo nė vienos $\langle\check{C}, \check{c}\rangle,\langle\breve{S}, \breve{s}\rangle$, $<\mathrm{V}, \mathrm{v}\rangle$. Kiek vèlesniame 1898-03-25 laiške (Didžiulienè 1898-03-25) vèl vyravo diakritinès raidès, jų santykis $\mathrm{su}\langle\mathrm{Cz}, \mathrm{cz}\rangle,\langle\mathrm{Sz}, \mathrm{sz}\rangle$ buvo 29 ir 1 , o viengubos $\langle\mathrm{V}, \mathrm{v}\rangle$ ir $\langle\mathrm{W}, \mathrm{w}\rangle-9$ ir 14 . Tačiau ir tuo metu virsmas neįvyko, naujieji ir ịprasti tradiciniai rašmenų variantai vartoti pramaišiui, santykis krypo čia ị vieną, čia ị kitą pusę. $1898 \mathrm{~m}$. rudenị sugrịžusi iš Griežionèliu ị Mintaują, Didžiulienè vèl daug dažniau rašè tik $\langle\mathrm{Cz}, \mathrm{cz}\rangle,\langle\mathrm{Sz}, \mathrm{sz}\rangle,\langle\mathrm{W}, \mathrm{w}\rangle$, plg. 1898-08-27 laišką (Didžiulienè 1898-08-27): <cz> galeczio 1, Rugpjuczio 1; $<$ sz $>$ asztůnius 1, susiszukůja 2; <w> parwažiawimo 1, tewas 3. Taip dvejopai Didžiulienè asmeninius raštus rašè dar kelerius metus. Paskutinis išlikęs tokią nenuoseklią rašybą reprezentuojantis jos rankraštis yra 1902-03-24 laiškas Didžiuliui (Didžiulienẻ 1902-03-24; žr. 2 lentelę).

Pereinamuoju Didžiulienès ortografijos laikotarpiu buvo išspausdinta keletas jos knygų. 1893-iaisiais Ūkininko išleistoje Lietuvos gaspadinēje (Ūkininko Nr. 4 priedas; [Didžiulienė] 1893a) vartoti šio periodinio leidinio rašmenys $\langle\mathrm{ie}\rangle,\langle\mathrm{uo}\rangle,\langle\mathrm{cZ}\rangle,\langle\mathrm{sz}\rangle,\langle\mathrm{l}\rangle$ [1], $\langle\mathrm{v}\rangle$, žymėtas [č'], [dž] minkštumas. Instr. sg. f. ir gen. pl. galūnès (plg. instr. sg. f. placzia žarna 6; gen. pl. pipiru grustu 6) irgi skyrėsi nuo Didžiulienès vartotų.

Tais pačiais metais ten pat išleista knygelè Negirdètas daiktas, ir Geros rodos musų moterelems (Ūkininko Nr. 10 priedas; [Didžiulienè 1893b]), kurios antrą dali - patarimus moterims, parašè Didžiulienė (kitą dali parašè Juozas Damijonaitis ir Antanas Kriščiukaitis-Aišbè). Didžiulienès teksto raidynas ir rašybos principai tokie pat kaip Lietuvos gaspadinēs (beje, Krikščiukaičio-Aišbès dalyje vartotos raidès $\langle\check{c}>,<\breve{s}>$ ).

Antrajame Lietuvos gaspadinès leidime 1895 m. ([Didžiulienè] 1895) rašmenys $\langle$ cZ $>,<$ sz $>$ pakeisti $<$ č $>$ (kviečia 3 ), $<$ Š $>$ (šiupinio 3 ). Čia vartota ir

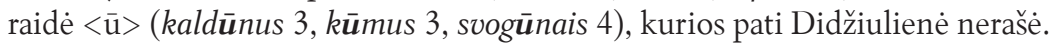
Taigi šiose knygose autorès ortografinès pažiūros neatsispindi.

\subsection{Orientacija ị periodikos kalbą ir bk}

Didžiulienès laiško Mečislovui Davainiui-Silvestraičiui, rašyto 1902-ųju pabaigoje (Didžiulienė 1902-12-23), rašyba daug vienodesnè. Galbūt tai lėmè ir adresatas - laiškas ne toks asmeniškas, kaip rašytieji vyrui. Čia tebevartota

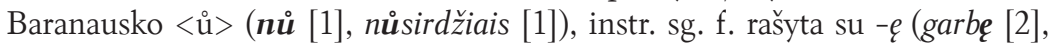
pagodonę [2]), gen. pl. su -u (musu [1], svetimu [1]). Bet jau nuosekliai vartotos diakritinès $<\check{c}>$ (ačiu [2], Viengenčio [1]), $<\breve{\text { S }, ~ s ̌>~(l a i s ̌ k a ~[1], ~ S ̌ v e n t e s ~ n o m . ~}$ pl. [1]). Taigi [č], [š] Didžiulienė dvejopai žymėjo nuo 1896 m. iki 1902 m. pabaigos.

Aptariamajame laiške vyravo ir $\langle\mathrm{v}\rangle$, jos santykis $\mathrm{su}\langle\mathrm{w}\rangle-16$ ir $3(<\mathrm{v}\rangle$ Dievo [1], bet ir $<\mathrm{w}>$ Diewu [2]). 
Iš kitų dvejų metų Didžiulienès rankraščių nèra išlikusių. 1904-05-03 sūnui Vytautui rašytame laiške (Didžiuliene 1904-05-03) [v] žymèjimas nebeįvairavo (viešejo 1, kviečia $1 \mathrm{v}$, buvau 1, užvažiavo 1). Taip pat netrukus, 1905-05-11, rašytas ir laiškas vyrui (Didžiulienè 1905-05-11) (vyresnybe 2, Vitautas 1). Vis dèlto, nors apsispręsta rašyti $\langle\mathrm{V}, \mathrm{v}\rangle$, igūdis dar nebuvo visai susiformavęs. Pavyzdžiui, 1906-02-06 laiške sūnui Antanui (Didžiulienė 190602-06) vèl pramaišiui su vyraujančia $\langle\mathrm{V}, \mathrm{v}\rangle$ pasitaike parašyti ir $\langle\mathrm{w}\rangle$ (ne dave $1 \mathrm{r}$, vieta $1 \mathrm{r}$ ir padawiau $1 \mathrm{r}$, wietos $1 \mathrm{r}$ ).

Svarbus Didžiulienès rašybos pokytis matyti 1904 m. gegužès mėnesio laiškuose (Didžiulienė 1904-05-03, 1905-05-11) - [uo] žymimas nebe < <uo> (Areštuotas 1905-05-11 [1], duot 1905-05-11 [1], Kurkliuose 1905-0511 [1], prisiruošus 1904-05-03 1). Tad 1904 m. Didžiulienė atsisakè maždaug trisdešimtį metų vartoto iš Baranausko išmokto rašmens $<\grave{u}>$ (dar žr. 2 lentelę). Taigi 1904 m. Didžiulienè jau buvo peremusi jablonskinès ortografijos rašmenis.

2 lentele

Liudvikos Didžiulienès ortografijos kaita

\begin{tabular}{|c|c|c|c|c|c|c|c|c|}
\hline & \begin{tabular}{|c|}
$1875-11-$ \\
$16-1881-$ \\
$09-05$
\end{tabular} & $\begin{array}{c}1885- \\
1888\end{array}$ & $\begin{array}{l}1895- \\
10-17\end{array}$ & 1896-09 & $\begin{array}{c}1897-03-01- \\
1902-03-24\end{array}$ & $\begin{array}{l}1902- \\
12-23\end{array}$ & $\begin{array}{l}1904- \\
05-03\end{array}$ & $\begin{array}{l}1923- \\
03-16\end{array}$ \\
\hline \begin{tabular}{|l}
{$[\mathrm{c}]$} \\
\end{tabular} & $\begin{array}{l}<\mathrm{cZ}> \\
<\mathrm{sz}>\end{array}$ & $\begin{array}{l}<\mathrm{cz}> \\
<\mathrm{sz}>\end{array}$ & $\begin{array}{l}<\mathrm{CZ}>, \\
<\mathrm{sz}>\end{array}$ & $\begin{array}{l}<\mathrm{CZ}>; \\
<\mathrm{SZ}>/ \\
<\mathrm{S}>\end{array}$ & $\begin{array}{l}<\mathrm{CZ}>/<\mathrm{C}> \\
<\mathrm{SZ}>/<\mathrm{s}>\end{array}$ & $\begin{array}{l}<\check{\mathrm{c}}>, \\
<\check{\mathrm{S}}>\end{array}$ & $\begin{array}{l}\check{c}>\text { C } \\
<\check{S}>\end{array}$ & $\begin{array}{l}<\check{\mathrm{c}}>, \\
<\check{\mathrm{s}}>\end{array}$ \\
\hline \begin{tabular}{|l}
{$[1]$} \\
\end{tabular} & $\langle 1\rangle$ & - & $<\mathrm{l}>$ & $<1>$ & $<\mathrm{l}>$ & $<1>$ & - & $<1>$ \\
\hline [v] & $\langle\mathrm{W}\rangle$ & $\begin{array}{l}<\mathrm{w}>/ \\
<\mathrm{v}>\end{array}$ & $\langle\mathrm{w}\rangle$ & $\langle\mathrm{w}\rangle$ & $\langle\mathrm{w}\rangle /<\mathrm{v}\rangle$ & $\begin{array}{l}<\mathrm{v}>/ \\
<\mathrm{w}\rangle\end{array}$ & $\langle\mathrm{v}\rangle$ & $\langle\mathrm{v}\rangle$ \\
\hline$[\mathrm{ie}]$ & $<\ddot{\mathrm{e}}>$ & \begin{tabular}{|l|}
$<\mathrm{ie}>/$ \\
$<\ddot{\mathrm{e}}>$
\end{tabular} & $<\mathrm{ie}>$ & $<\mathrm{ie}>$ & $\langle\mathrm{ie}>$ & $<\mathrm{ie}>$ & $<\mathrm{ie}>$ & $<\mathrm{ie}>$ \\
\hline \begin{tabular}{|l}
$\mathrm{uo}]$ \\
\end{tabular} & $<\stackrel{\text { ů }}{ }\rangle$ & $<\stackrel{\mathrm{u}}{ }\rangle$ & $<\stackrel{\circ}{\mathrm{u}}\rangle$ & $\langle\stackrel{\circ}{\mathrm{u}}\rangle$ & $<\stackrel{\mathrm{u}}{ }\rangle$ & $<\stackrel{\circ}{\mathrm{u}}\rangle$ & $\langle\mathrm{uO}\rangle$ & $<$ uo $>$ \\
\hline ['̌́'], [dž'] & $\begin{array}{l}<\mathrm{cz}> \\
<\mathrm{dž}\rangle\end{array}$ & $<\mathrm{cz}>$ & $\begin{array}{l}<\text { czi }>, \\
<\text { dži }>\end{array}$ & $\begin{array}{l}<\text { czi }>\text {, } \\
<\text { dži }>\end{array}$ & $\begin{array}{l}<\text { czi }>\text {, } \\
<\text { dži }>\end{array}$ & $\begin{array}{l}<\text { či }>, \\
<\text { dži }>\end{array}$ & $<$ či $>$ & $\begin{array}{l}<\text { či }>, \\
<\text { dži }>\end{array}$ \\
\hline instr. sg. f. & $-q,-e$ & - & $-q$, & $-q,-e$ & $-q,-q$ & $-e$ & - & $\begin{array}{l}-q,-e / \\
-a,-e\end{array}$ \\
\hline gen. pl. & $-u$ & - & $-u$ & $-u$ & $-u$ & $-u$ & - & $-u /-u$ \\
\hline
\end{tabular}

Iš Didžiulienès 1910 m. pradžioje rašyto laiško (Didžiulienè 1910-02-01) matyti, kad ir tada (i $i) \bar{a}$ kamieno instr. sg. ji vis dar rašè su -q (Su didžia pagar$b \boldsymbol{q}$ [2]), gen. pl. - su galūne -u (minetuju raštu gen. pl. [1]). Šie rašybos ịpročiai išliko ir 1923 m. (Didžiulienè 1923-03-16): instr. sg. f. su dviguba energija [1], su Misiutę [2]; gen. pl. metu [2], musu [1], visu [1], nors pasitaikè ir baltiniu [2], gilzu [2], popereliu [2], šiltų rubu [2].

Kaip matyti, aštuntajame dešimtmetyje apsisprendusi rašyti pagal Baranausko rbk modelį, Didžiulienè jo laikèsi iki devintojo dešimtmečio pabaigos. Vèliau 
jos ortografijai būdingas įvairavimas, ypač priebalsių [č ], [s] ir [v] žymèjimo. Nors apie 1904 m. Didžiulienè jau rašè nuosekliai jablonskiškai, tačiau Baranausko rbk instr. sg. f. ir gen. pl. galūnes ji žymèjo ir trečiajame XX a. dešimtmetyje.

\section{Išvados}

1. Antano Baranausko sukurtu lietuvių rašomosios kalbos modeliu XIX a. paskutiniaisiais dešimtmečiais rèmėsi ne tik Žemaičių (Telšių) vyskupijos centro ir dvasinès seminarijos atstovai, bet ir kai kurie pasauliečiai.

2. Baranausko rašomosios kalbos principais XIX a. aštuntajame dešimtmetyje vadovavosi Stanislovas ir Liudvika Didžiuliai. Jie vartojo tuo metu iprastus ir Baranausko rbk būdingus rašmenis $\langle\mathrm{cz}\rangle,\langle\mathrm{sz}\rangle,\langle\mathrm{l}\rangle[1],\langle\mathrm{W}\rangle$,

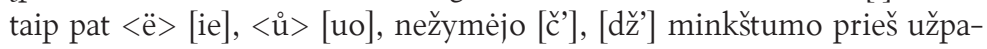
kalinès eilès balsius, (i) $\bar{a}, \bar{e}$ kamienų vardažodžių instr. sg. galūnèje rašè nosinius balsius žyminčias $-q,-\ell$, o gen. pl. $--u$.

3. Dar prieš pasirodant Aušrai, apie 1882 m., Didžiulis èmé abejoti dèl savo rašomosios kalbos pasirinkimo - Baranausko rbk jis nebesilaikè taip nuosekliai. Devintąij dešimtmetị Didžiulis tarsi lūkuriavo, kuri ortografija ịsitvirtins, pagal poreiki remdamasis Baranausko ar periodinès spaudos kalbos modeliu ir rašydamas $\langle$ CZ $>$ ar $\langle$ ç $\rangle,\langle$ sZ $>$ ar $\langle$ Š $\rangle,\langle\nmid\rangle[1]$ ar $\langle\mathrm{l}\rangle$, $<$ li $>$ [l'] ar $\langle\mathrm{l}\rangle,\langle\mathrm{w}\rangle$ ar $\langle\mathrm{v}\rangle,\langle\ddot{\mathrm{e}}\rangle$ ar $\langle$ ie $\rangle,\langle\dot{\mathrm{u}}\rangle$ ar $\langle$ uo $\rangle$, žymèdamas ar nežymėdamas [dž’] minkštumą.

1897-1898 m., tad dar neišẻjus iš spaudos 1901 m. Jablonskio gramatikai, Didžiulis atsisake Baranausko rbk ir perėmè vis didesni prestižą ígyjančios

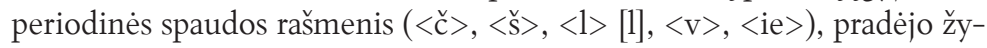
mèti [č'], [dž’] minkštumą prieš užpakalinès eilès balsius. Tokią ortografijos permainą veikiausiai lèmé bendravimas su varpininkais ir bendradarbiavimas jų spaudoje, stiprejjantis periodikos kalbos prestižas. Rašmens $<\stackrel{\mathrm{u}}{ }$, (i) $\bar{a}, \bar{e}$ kamienų vardažodžių instr. sg. galūnių -(i)a, , - , gen. pl. - $u$ Didžiulis nebekeitè, nors šios Baranausko rbk ypatybès neatitiko Jablonskio ortografijos normų.

Taigi iki 1882 m. Didžiulis laikèsi Baranausko rbk principų, 1882-1897 m. rašè mišriai, o $1897 \mathrm{~m}$. pabaigoje perèmé pasaulietinès periodikos ortografiją.

4. Liudvika Didžiulienė, aštuntajame dešimtmetyje rašiusi pagal Baranausko gramatikos principus, devintojo dešimtmečio viduryje savo rašybą ėmė kreipti ị periodikos kalbos pusę. $1895 \mathrm{~m}$. ji neberaše Baranausko $<\ddot{\mathrm{e}}>$, tradicinès $<\nmid>$, žymėjo [č'], [dž’] minkštumą prieš užpakalinės eilès balsius. Tačiau maždaug šešerius metus, iki 1902 m. pradžios laiškuose ji dvejopai

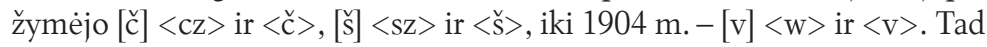
1901 m. pasirodžius Jablonskio gramatikai, jos normų perimti neskubèta. 
(i) $\bar{a}, \bar{e}$ kamienų vardažodžių instr. sg. Didžiulienè ir XX a. teberašè su -q, $-\ell$, gen. pl. $-\mathrm{su}-u$, nors $1923 \mathrm{~m}$. pramaišiui parašydavo ir $-u$.

Taigi Didžiulienė 1875-1881 m. rašè baranauskiškai, paskui rašyba įvairavo iki $1904 \mathrm{~m}$. Vèliau perimtos periodikos ir Jablonskio gramatikos ortografijos normos. Vadinasi, per du paskutiniuosius XIX a. dešimtmečius periodikos kalba, jos prestižas sustiprẻjo tiek, kad Didžiuliai atsisakè Baranausko ortografijos principų ir èmè rašyti pagal laikraščiu pavyzdị.

\section{Santrumpos}

KTUB $=\quad$ Kauno technologijos universiteto biblioteka.

LLTIBR $=\quad$ Lietuvių literatūros ir tautosakos instituto bibliotekos rankraštynas.

LMAVB RS $=$ Lietuvos mokslų akademijos Vrublevskių bibliotekos rankraščių skyrius.

LNMMB RS = Lietuvos nacionalinès Martyno Mažvydo bibliotekos rankraščių skyrius.

VUB RS $=\quad$ Vilniaus universiteto bibliotekos rankraščiu skyrius.

\section{Šaltiniai ir literatūra}

Anykštènų biografijų žinynas (www.anykstenai.lt/asmenys/asm.php?id=87).

Baranauskas, Antanas.

1872-12-21.

[Basanavičius, Jonas.] 1884.

[Basanavičius, Jonas.] 1899.

B[iržiška], V[a]c[lovas].

1954a.

B[iržiška], V[a]c[lovas].

1954b.

Didžiulienė, Liudvika. [b. d.]

[Didžiulienè, Liudvika.]

1893a.

[Didžiulienė, Liudvika.]

1893b.

[Didžiulienè, Liudvika.] 1895.

Didžiulienė, Liudvika. 1895-10-17.

Didžiulienė, Liudvika.

1896-09-15.

Didžiulienė, Liudvika.

1897-03-01.

Didžiulienè, Liudvika.

1897-05-04.
Laiškas Stanislovui Didžiuliui iš Kauno. Antanas Baranauskas. Raštai VII/1. Dienoraštis. Laiškai ịvairiems adresatams, sudare Regina Mikšytė, Marius Daškus, verte Regina Mikšyte, Vilnius: Lietuvių literatūros ir tautosakos institutas, Baltos lankos, 2003, 161.

Oškabaliun dainos, surinktos ir išdůtos per Jonan Basanaviţiun. Tylźeje: Spaustuvej' Otto iš Mauderodes.

Prie historijos musun rašybos. Parašè dr. J. Basanaviţius. Tilžeje: Spaustuveje otto v. Mauderodes.

Didžiulis Stanislovas. Lietuvių enciklopedija 4. Boston: Lietuvių enciklopedijos leidykla, 528-529.

Didžiulienè-Nitaite Liudvika. Lietuviu enciklopedija 4. Boston: Lietuvių enciklopedijos leidykla, 526-527.

Atsiminimai (rankraštis). VUB RS: F 1 - D 482.

Lietuvos gaspadinē arba pamokinimai kaip prigulincziai suvartoti Dievo dovanas. Paraszė Žmona. Tilžèje.

Negirdētas daiktas ir geros rodos musų moterelems. Tilžēje.

Lietuvos gaspadine arba pamokinimai kaip prigulinčiai suvartoti dievo dovanas. Parašě Žmona. Tilžeje: Išleista M. Noveskio.

Laiškas Stanislovui Didžiuliui (rankraštis). LMAVB RS: F 94 $15 / 7$.

Laiškas Stanislovui Didžiuliui (rankraštis). LLTIBR: F 1 - 513/1.

Laiškas Stanislovui Didžiuliui iš Jelgavos (rankraštis). LLTIBR: F $1-513 / 2$.

Laiškas Stanislovui Didžiuliui iš Jelgavos (rankraštis). LLTIBR: F $1-513 / 2$. 
Didžiulienè, Liudvika. 1897-08-25.

Didžiulienè, Liudvika. 1898-02-28.

Didžiulienè, Liudvika. 1898-03-25.

Didžiulienė, Liudvika. 1898-08-27.

Didžiulienè, Liudvika. 1902-03-24.

Didžiulienè, Liudvika. 1902-12-23.

Didžiulienè, Liudvika. 1904-05-03.

Didžiulienè, Liudvika. 1905-05-11.

Didžiulienè, Liudvika. 1906-02-06.

Didžiulienè, Liudvika. 1910-02-01.

Didžiulienė, Liudvika. 1923-03-16.

Didžiulis, Stanislovas. [b. d.]

Didžiulis, Stanislovas,

Liudvika Didžiulienè. [b. d.]

Didžiulis, Stanislovas,

Liudvika Didžiulienè.

1878-11-29.

Didžiulis, Stanislovas. 1872.

Didžiulis, Stanislovas.

[1875-1882.]

Didžiulis, Stanislovas. 1881.

Didžiulis, Stanislovas.

1889-03-24.

Didžiulis, Stanislovas. 1890.

Didžiulis, Stanislovas. 1897-12-08.

Didžiulis, Stanislovas. 1897-12-26.

Didžiulis, Stanislovas. 1898-01-14.

Didžiulis, Stanislovas. 1898-01-28.
Laiškas Stanislovui Didžiuliui (rankraštis). LLTIBR: F 1 - 513/2.

Laiškas Stanislovui Didžiuliui iš Jelgavos (rankraštis). LLTIBR: F $1-513 / 3$.

Laiškas Stanislovui Didžiuliui iš Mintaujos (rankraštis). LLTIBR: F $1-513 / 3$.

Laiškas Stanislovui Didžiuliui iš Mintaujos (rankraštis). LLTIBR: F $1-513 / 3$.

Laiškas Stanislovui Didžiuliui iš Mintaujos (rankraštis). LLTIBR: F 1 - 513/8.

Laiškas Mečislovui Davainiui-Silvestraičiui (rankraštis). LLTIBR: F 1 - 1834.

Laiškas Vytautui Didžiuliui (rankraštis). LMAVB RS:F 94 - 3/4.

Laiškas Stanislovui Didžiuliui iš Vilniaus (rankraštis). LLTIBR: F $1-513 / 7$.

Laiškas Antanui Didžiuliui (rankraštis). LMAVB RS: F 94 - 3/2.

Laiškas Lietuvių mokslo draugijai (rankraštis). LLTIBR:F 1 - 183.

Laiškas Antanui Kazanavičiui (rankraštis). (www.limis.lt/ detali-paieska/perziura/-/exhibit/preview/191987489?s_ $\mathrm{id}=2119 \mid 1 Z \mathrm{~d} 1 \mathrm{YBY}$ rSic\&s_ind=7\&valuable_type $=$ EKSPONATAS) .

Laiškas nenustatytam asmeniui (Keli žodžai ape mano kałbą ir raszyba) (rankraštis). LMAVB RS: F 94 - AK-128 St.

Senųjų kalbos (rankraštis); VUB RS: F 1 - D 568.

Laiškas Antanui Baranauskui iš Griežionèlių (rankraštis). VUB RS: F 1 - E 359.

Priežodžiai, patarlès, papročiai, mịslès, burtai ir pasakos (rankraštis). LMAVB RS: F 12 - 464.

Ape Tryszimą. Didžiulių ūkio Giežionèlèse dirvų tręšimo 18751882 žiniaraštis (rankraštis). LMAVB RS: F 94 - 11/21.

Dainos. Sutartinès (rankraštis). LMAVB RS: F $94-45$.

Laiškas nenustatytam asmeniui [vyskupui] iš Griežionèlių (juodraštis, rankraštis). LMAVB RS: F 94 - 11/8.

Laiškas Martynui Jankui ir sakme Voras (rankraštis). VUB RS: F 1 - D 409.

Laiškas Liudvikai Didžiulienei iš Griežionèlių (rankraštis). LMAVB RS: F $94-7 / 8$.

Laiškas Liudvikai Didžiulienei iš Griežionèlių (rankraštis). LMAVB RS: F 94 - 4/1.

Laiškas Liudvikai Didžiulienei iš Griežionèlių (rankraštis). LMAVB RS: F 94 - 4/1.

Laiškas Liudvikai Didžiulienei iš Griežionèlių (rankraštis). LMAVB RS: F 94 - 4/1. 
Didžiulis, Stanislovas.

1910-12-30.

Didžiulis, Stanislovas.

1912-06-17.

Didžiulis, Stanislovas.

1915-03-19.

Didžiulis, Stanislovas.

1916-04-29.

Didžiulis, Stanislovas.

1916-06-16.

Jakštas[-Dambrauskas],

A[domas]. 1914.

Jonikas, Petras. 1972.

Jonikas, Petras. 1987.

Kaluškevičius, Benjaminas,

Kazys Misius. 2004.

Lietuvninkaitè, Nijolè.

2004a.

Lietuvninkaite, Nijole [par.] 2004b.

LKŽe =

[Miliauskas-Miglovara,

Juozapas.] 1883.

Nitaitè, Liudvika.

1875-11-16.

Spudulis, Jonas. 1883-12-03.

Venckienè, Jurgita. 2007.

Venckiené, Jurgita. 2014.

Žukas, Vladas. 2003-08-06.
Laiškas Liudvikai Didžiulienei (rankraštis). LMAVB RS: F 94 16/13.

Laiškas Liudvikai Didžiulienei (rankraštis). LMAVB RS: F 94 6/8.

Laiškas Liudvikai Didžiulienei (rankraštis). LMAVB RS: F 94 $16 / 13$

Laiškas Vandai Didžiulytei (rankraštis). LMAVB RS: F 94 - 7/9.

Laiškas Vandai Didžiulytei (rankraštis). LMAVB RS: F 94 - 7/9.

Musų alfabeto klausimas. Kaunas: Saliamono Banaičio spaustuvè.

Lietuvių bendrinès rašomosios kalbos kürimasis antrojoje XIX a. pusëje. Čikaga: Pedagoginis lituanistikos institutas.

Lietuvių kalba ir tauta amžiu būvyje. Visuomeniniai lietuvių kalbos istorijos bruožai. Chicago: Lituanistikos instituto leidykla.

Lietuvos knygnešiai ir daraktoriai. 1864-1904. Vilnius: Diemedžio leidykla.

Stanislovas Didžiulis - spaudos draudimo epochos bibliofilas. Stanislovo Didžiulio asmenine biblioteka, parengè Nijolè Lietuvninkaitè. Kaunas: Technologija, 9-29.

Stanislovo Didžiulio asmeniné biblioteka, Kaunas: Technologija.

Lietuvių kalbos žodynas 1-20. 1941-2002. Elektroninis variantas, redaktorių kolegija: Gertrūda Naktinienė (vyr. redaktorè), Jonas Paulauskas, Ritutė Petrokienè, Vytautas Vitkauskas, Jolanta Zabarskaité, programuotojai: Evaldas Ožeraitis, Vytautas Zinkevičius. Vilnius: Lietuvių kalbos institutas. 2005 (atnaujinta versija 2017). (www.lkz.lt.).

Poczta Litewsko-Literacka (Raszliavos Pacztas) (rankraštis). KTUB: Rš 2017.

Laiškas Stanislovui Didžiuliui (rankraštis). LMAVB RS: F 94 $34 / 24$.

Laiškas Aleksandrui Dambrauskui iš Peterburgo (rankraštis). VUB RS: F 1 - D 462.

Lietuvių bendrinès kalbos pradžia: idëjos ir jų sklaida(1883-1901), Vilnius (daktaro disertacija).

Antano Baranausko lietuvių bendrinès kalbos teorija: priemimas Žemaičių kunigų seminarijoje. Archivum Lithuanicum 16, 269-294.

Didžiùlis Stanislovas. Visuotine lietuvių enciklopedija (www.vle.lt/ Straipsnis/Stanislovas-Didziulis-64973).

Jurgita Venckiene

Raštijos paveldo tyrimų centras

Lietuviu kalbos institutas

P. Vileišio 5, LT-10308 Vilnius, Lietuva

jurgita.venckiene@lki.lt 
KOPSAVILKUMS

\title{
Stanislova un Ḷudvikas Didžuḷu lietotās ortogrāfijas maiṇa: no Antana Baranauska uz kopvalodas standartu
}

\author{
Jurgita VENCKIENÉ
}

Raksts turpina Antana Baranauska radītās lietuviešu rakstu valodas izplatī̌nanās izpēti. Tajā analizēta viņa sekotāju Stanislova Didžuḷa, kas pazīstams ar savu lietuviešu bibliotēku un preses izplatǐšanu, un rakstnieces Ļudvikas Nitaites-Didžulienes-Žmonas valodas maiņa.

19. gadsimta 70. gados Didžuḷi sekoja Baranauska lietuviešu rakstu valodas standarta principiem. Viņi lietoja grafēmas $\langle\mathrm{cz}\rangle,\langle\mathrm{sz}\rangle,\langle\mathrm{t}\rangle,\langle\mathrm{w}\rangle,\langle\ddot{\mathrm{e}}\rangle$ [ie], $\langle$ ů $\rangle$ [uo], neapzīmēja [č'], [dž’] palatalizāciju, (i) $\bar{a}-$ un $\bar{e}$-celma vārdu vsk. instr. lietoja galotnes $-q$, $-e$, dsk. ğen. $--u$.

1882. gadā Didžulis sāka šaubīties par rakstu valodas izvēli - viņš vairs tik konsekventi nesekoja Baranauska principiem. Viņš vēroja, kura ortogrāfija kḷ̂̄s par standartu, un pēc vajadzības palāāās uz Baranauska vai periodikas ortogrāfiju, rakstot $\langle$ cz $\rangle$ vai $\langle$ ç $\rangle,\langle$ sz $\rangle$ vai $\langle$ š $\rangle,\langle$ ł $\rangle$ vai $\langle\mathrm{l}\rangle,\langle\mathrm{w}\rangle$ vai $\langle\mathrm{v}\rangle,\langle\ddot{\mathrm{e}}\rangle$ vai $\langle\mathrm{ie}\rangle,\langle\mathrm{u}\rangle$ vai $\langle$ uo $\rangle$.

1897.-1898. gadā Didžulis pieņēma periodisko izdevumu ortogrāfiju $(<\mathrm{c}>,<$ š $\rangle,<1>,<\mathrm{v}\rangle$, <ie> un sāka apzīmēt [č’], [dž’] palatalizāciju), kuras prestižs pieauga.

Didžuliene arī pielāgoja savu ortogrāfiju periodiskajos izdevumos lietotajai 19. gadsimta 80. un 90. gadu mijā. 1895. gadā viņa vairs nerakstīja $\langle\ddot{e}\rangle,\langle\nmid\rangle$, atzīmēja [č’], [dž’] palatalizāciju. Tomēr līdz 20. gadsimta sākumam viņa turpināja lietot $\langle$ cz $>$ un $\langle$ č $\rangle,\langle$ sz $\rangle$ un $\langle\grave{s}\rangle,\langle$ w $\rangle$ un $\langle$ v $\rangle$.

Periodisko izdevumu un to valodas prestižs 19. gadsimta pēdējās divās desmitgadēs bija kḷuvis tik spēcīgs, lai konkurētu ar citiem lietuviešu valodas standarta modẹiem.

\section{SUMMARY}

\section{The Change of Orthography Used by Stanislovas and Liudvika Didžiuliai: from Antanas Baranauskas to Standard Language}

\author{
Jurgita VENCKIENÉ
}

The article continues the research of the dissemination of Antanas Baranauskas'written Standard Lithuanian. The change of language of his followers Stanislovas Didžiulis, famous for his Lithuanian library and press distribution, and writer Liudvika Nitaitė-Didžiulienė-Žmona is analyzed.

In the 1870s, Didžiuliai followed the principles of Baranauskas' written Standard Lithuanian. They used graphemes $\langle\mathrm{cz}\rangle,\langle\mathrm{sz}\rangle,\langle\mathrm{l}\rangle,\langle\mathrm{w}\rangle,\langle\ddot{\mathrm{e}}\rangle$ [ie], $\langle\stackrel{\mathrm{u}}{\rangle}$ [uo], did not mark the softness of [č'], [dž], wrote instr. sg. of (i) $\bar{a}, \bar{e}$ stems with the endings $-q,-e$, gen. pl. - with $-u$.

In 1882 Didžiulis started to have doubts about his choice of written language - he did not follow Baranauskas' principles so consistently. He was on the watch for which orthography would become a standard and relied on Baranauskas or the periodical press orthography as needed, writing $\langle$ cz $\rangle$ or $\langle$ ç $\rangle,\langle$ sz $\rangle$ or $\langle$ š $\rangle,\langle\mathrm{l}\rangle$ or $\langle\mathrm{l}\rangle,\langle\mathrm{w}\rangle$ or $\langle\mathrm{v}\rangle,\langle\ddot{\mathrm{e}}\rangle$ or $\langle\mathrm{ie}\rangle,\langle\stackrel{\circ}{\mathrm{u}}\rangle$ or $\langle\mathrm{uO}\rangle$.

In 1897-1898 Didžiulis adopted the orthography of periodicals $(<\check{\mathrm{c}}\rangle,\langle\mathrm{s}\rangle,\langle\mathrm{l}\rangle,\langle\mathrm{v}\rangle,\langle\mathrm{ie}\rangle$, and started to mark the softness of [č'], [dž’]), gaining increasing prestige.

Didžiulienè also re-aligned her orthography with that of the periodicals at the turn of the ninth and tenth decades of the $19^{\text {th }}$ century. In 1895 she did not write $<\ddot{e}>,<\nmid>$, marked the softness of [č'], [dž']. However, by the beginning of the $20^{\text {th }}$ century she wrote both $\langle\mathrm{cz}\rangle$ and $\langle\check{\mathrm{c}}\rangle,\langle$ sz $>$ and $\langle\mathrm{s}\rangle,\langle\mathrm{w}\rangle$ and $\langle\mathrm{v}\rangle$.

The prestige of periodicals and their language strengthened to the point of competing with other models of standard Lithuanian over the last two decades of the $19^{\text {th }}$ century. 